\title{
Influence of protein-calorie malnutrition on the pharmacokinetics, placental transfer and tissue localization of dexamethasone in rats
}

\author{
D.R. Varma \& T.L. Yue
}

Department of Pharmacology \& Therapeutics, McGill University, 3655 Drummond Street, Montreal, Quebec, Canada H3G 1 Y6

1 The influence of protein-calorie malnutrition (PCM) on the pharmacokinetics, transplacental passage and tissue localization of dexamethasone was determined in Sprague-Dawley rats.

2 PCM increased the plasma half-life and volume of distribution of dexamethasone in pregnant but not in nonpregnant rats.

3 Ratios of foetal to maternal serum dexamethasone concentrations were $0.2-0.4$ at different dose levels $\left(0.8-20 \mu \mathrm{mol} \mathrm{kg}^{-1}\right)$, time intervals $(0.25-12 \mathrm{~h})$ and gestational ages (day 14-21).

4 PCM increased the foetal serum and tissue concentrations of dexamethasone but exerted no significant effect on its binding to maternal and foetal serum proteins or on its metabolism by the placenta.

5 It is suggested that significantly lower foetal than maternal serum levels of dexamethasone are due to efficient elimination of this agent by the foeto-placental unit and an impairment of this mechanism may account for the observed increase in dexamethasone levels in the foetuses of PCM rats.

\section{Introduction}

Glucocorticoids are an important group of drugs with therapeutic indications ranging from minor skin diseases to life-threatening situations. The likelihood of ingestion of these agents by pregnant women including those suffering from protein-calorie malnutrition (PCM) is quite high. Glucocorticoids are teratogenic agents (Fraser et al., 1954) and even a single dose can adversely affect foetal and subsequent development (Avery, 1975). These effects of glucocorticoids will be influenced by the magnitude of their transplacental passage and localization in foetal tissues. Because PCM was found to alter the placental transfer of the nonsteroidal anti-inflammatory agent salicylate (Varma \& Yue, 1983), we determined any influence of this condition on the transplacental passage and pharmacokinetics of dexamethasone in rats as the experimental model. It was found that PCM increased the foetal serum and tissue concentrations of maternally ingested dexamethasone.

\section{Methods}

Animals, diet and general procedures

Virgin Sprague-Dawley female rats weighing between 200-225 g (10-11 weeks old) were housed with males during the night and the following morning was designated as day zero of pregnancy for animals with evidence of sperm in the vaginal washings. In addition a number of nonpregnant rats of similar body weight and age were also used. Animals had free access to tap water and a $21 \%$ (control) or a $5 \%$ (PCM) protein diet (Mulay et al., 1982; Varma \& Yue, 1983). The composition of the control $21 \%$ protein diet was as follows $\left(\mathrm{g} \mathrm{kg}^{-1}\right)$ : vitamin-free casein 231 , sucrose 519 , corn starch 150 , corn oil 50 , mineral mixture (Williams-Briggs) 40 and vitamin mixture (Teklad) 10 . The $5 \%$ protein diet contained $55 \mathrm{~g} \mathrm{~kg}^{-1}$ vitamin-free casein and $695 \mathrm{~g} \mathrm{~kg}^{-1}$ sucrose; all other constituents were identical to those in the 
control diet. Both diets were isocaloric in composition and were purchased from Teklad Test Diets, Madison, Wisconsin, U.S.A. Animals fed the 5\% protein diet were treated as suffering from proteincalorie malnutrition (PCM).

Intravenous injections and collections of blood and tissue samples were all done under ether anaesthesia. Pharmacokinetic studies were done on day 20 of gestation or equivalent periods of the two dietary regimens in the case of nonpregnant rats. Transplacental passage of dexamethasone was determined at days 14-21 of gestation. For the pharmacokinetic studies, blood (0.1-0.2 ml) was collected from the tail artery. In studies on the transplacental passage of dexamethasone, a single maternal blood sample was collected by cardiac puncture; foetuses were removed by caesarian section, amniotic fluid was drained and carefully wiped off the bodies of the foetuses and blood was collected following decapitation. Placental metabolism of dexamethasone was studied with fresh tissues; in other cases tissues were stored at $-20^{\circ} \mathrm{C}$ until analysed.

\section{Dexamethasone pharmacokinetics}

Dexamethasone phosphate $\left(4 \mu \mathrm{mol} \mathrm{kg}^{-1}\right)$ was injected into the tail vein and blood samples were collected at 1, 3, 6, 9, 12 and $24 \mathrm{~h}$. Plasma half-life $\left(t_{1 / 2}\right)$, apparent volume of distribution $\left(\mathrm{V}_{\mathrm{d}}\right)$ and plasma clearance $\left(\mathrm{Cl}_{\mathrm{p}}\right)$ were determined by nonlinear least square regression analysis of the serum dexamethasone concentration data according to a onecompartment open model (Varma \& Mulay, 1980). Serum dexamethasone levels at $24 \mathrm{~h}$ were too low and not included in the analysis of pharmacokinetic parameters.

Transplacental passage of dexamethasone as a function of time, dose and gestational age

In order to determine the time-course of maternalfoetal distribution of dexamethasone, $4 \mu \mathrm{mol} \mathrm{kg}^{-1}$ dexamethasone was injected (i.v.) on day 20 of gestation and maternal blood and liver, foetal blood, livers and lungs, placentas as well as amniotic fluid were collected at $0.25,1,3,6,9,12$ or $24 \mathrm{~h}$. In other experiments, $0.8,4$ or $20 \mu \mathrm{mol} \mathrm{kg}^{-1}$ dexamethasone was injected (i.v.) on day 20 of gestation and maternal and foetal blood as well as amniotic fluid samples were collected at $3 \mathrm{~h}$. Also, the distribution of dexamethasone $3 \mathrm{~h}$ following its intravenous injection $\left(4 \mu \mathrm{mol} \mathrm{kg}^{-1}\right)$ was determined on day $14,17,19,20$ and 21 of gestation.

\section{Placental metabolism of dexamethasone}

Placentae were removed on day 20 of gestation and immediately minced into a small pieces. Approxi- mately $1 \mathrm{~g}$ tissue was incubated with $5 \mathrm{ml}$ of Krebs buffer (pH 7.4) containing 1,2 or $4 \mu \mathrm{M}$ dexamethasone at $37^{\circ} \mathrm{C}$ for $3 \mathrm{~h}$ under a stream of $95 \% \mathrm{O}_{2}$ and $5 \% \mathrm{CO}_{2}$ (Blanford \& Murphy, 1977). At the end of the incubation, samples were extracted with methylene chloride and assayed for dexamethasone and metabolite(s) by h.p.l.c. (Kream et al., 1983).

\section{Serum protein-dexamethasone binding}

The binding of dexamethasone to maternal and foetal serum proteins was determined by equilibrium dialysis at $37^{\circ} \mathrm{C}$ for $48 \mathrm{~h}$ (Westphal, 1969). Serum samples were diluted with $0.05 \mathrm{M}$ phosphate buffer (pH 7.4) in a ratio of 1 to $10 ; 2 \mathrm{ml}$ of the diluted serum was placed inside a cellulose dialysis bag $(1 \mathrm{~cm}$ long, 12,000 molecular weight cut-off), which was then placed in $10 \mathrm{ml}$ of the phosphate buffer containing $\left[{ }^{3} \mathrm{H}\right]$-dexamethasone $(0.62,10.8$ or $102.5 \mathrm{nM})$ and antibiotics (streptomycin $0.05 \mathrm{mg} \mathrm{ml}^{-1}$ and penicillin $50 \mathrm{u} \mathrm{ml}^{-1}$ ). In preliminary experiments it was found that the binding of dexamethasone to serum proteins did not change with increases in the concentration of the steroid up to $2.5 \mathrm{nmol} \mathrm{ml}^{-1}$ suggesting that the binding was not saturable; in this sense, the binding data might represent partitioning of the steroid between the protein and nonprotein constituent of the serum. The binding to undiluted serum was calculated on the basis of its protein concentration.

\section{Assay of dexamethasone and metabolites}

With the exception of studies on placental metabolism, dexamethasone concentrations were determined by radioimmunoassay (Varma \& Mulay, 1980). Dexamethasone and 11-dehydrodexamethasone in placental minces were measured by h.p.l.c. (Kream et al., 1983) by means of a $\mu$ Bondapak $\mathrm{C}_{18}$ reverse-phase column (Waters) and a mobile phase of acetonitrile : methanol : water $(25: 25: 50)$ at a flow rate of $1 \mathrm{ml} \mathrm{min}^{-1}$ delivered by an Altex pump (Varma \& Yue, 1983). Prednisolone was used as the internal standard and the absorbance was measured at $254 \mathrm{~nm}$. [ $\left.{ }^{3} \mathrm{H}\right]$-dexamethasone was quantitated by scintillation spectrometry (Intertechnique).

\section{Other determinations and statistics}

Proteins were measured according to Lowry et al. (1951) with bovine serum albumin as the standard. Group means were compared by one-way analysis of variance followed by comparisons of each two means (Bonferroni). Differences between two means were tested by Student's $t$ test for unpaired data. A probability of less than 0.05 was assumed to denote a significant difference. Throughout this paper means \pm s.e. are presented. 
Table 1 Influence of protein-calorie malnutrition (PCM) on the pharmacokinetics of dexamethasone $\left(4 \mu \mathrm{mol} \mathrm{kg}{ }^{-1}\right.$, i.v. $)$ in nonpregnant and pregnant (day 20 of gestation) rats

\begin{tabular}{|c|c|c|c|c|}
\hline Animals & $\mathbf{n}$ & $\begin{array}{l}t_{1 / 2} \\
(h)\end{array}$ & $\begin{array}{c}V_{\mathrm{d}} \\
\left(\mathrm{ml} \mathrm{kg}^{-1}\right)\end{array}$ & $\underset{\left(\mathrm{ml} \mathrm{kg}^{-1} \mathrm{~h}^{-1}\right)}{C l_{\mathrm{p}}}$ \\
\hline \multicolumn{5}{|l|}{ Nonpregnant } \\
\hline Control & 7 & $2.7 \pm 0.3$ & $604 \pm 55$ & $170 \pm 28$ \\
\hline $\begin{array}{l}\text { PCM } \\
\text { Pregnant }\end{array}$ & 6 & $3.3 \pm 0.4$ & $605 \pm 50$ & $137 \pm 19$ \\
\hline Control & 6 & $3.1 \pm 0.3$ & $726 \pm 69$ & $161 \pm 18$ \\
\hline PCM & 5 & $4.5 \pm 0.5^{*}$ & $1150 \pm 60^{* *}$ & $182 \pm 18$ \\
\hline
\end{tabular}

\section{Drugs and chemicals}

The following agents were purchased: dexamethasone, prednisolone and bovine serum albumin (Sigma Chemical Co., St. Louis, Missouri, U.S.A.); $\left[6,7-{ }^{3} \mathrm{H}\right]$-dexamethasone $\left(50 \mathrm{Ci} \mathrm{mmol}^{-1}\right.$, New England Nuclear, Boston, Massachusetts, U.S.A.). Dexamethasone phosphate was a gift from Merck Frosst Laboratories, Dorval, Quebec, Canada. Antisera against dexamethasone - 3 - carboxymethyloxime - bovine serum albumin conjugate was kindly provided by $\operatorname{Dr} S$. Solomon, Endocrine Laboratory, Royal Victoria Hospital, McGill University, Montreal, Canada. 11-Dehydrodexamethasone was a gift from Dr T.L. Popper, Schering Corporation, Bloomfield, New Jersey, U.S.A.

\section{Results}

General effects of protein-calorie malnutrition (PCM)

As found previously (Mulay et al., 1982; Varma \& Yue, 1983), PCM led to a decrease in body weight gain by nonpregnant and pregnant rats as well as a decrease in foetal body weights, and weights of maternal and foetal livers, foetal lungs and placentas. The litter size was not affected by PCM.

\section{Dexamethasone pharmacokinetics (Table 1)}

PCM did not significantly alter the plasma half-life $\left(t_{1 / 2}\right)$, apparent volume of distribution $\left(\mathrm{V}_{\mathrm{d}}\right)$ and plasma clearance $\left(\mathrm{Cl}_{\mathrm{p}}\right)$ of dexamethasone in nonpregnant

Table 2 Influence of protein-calorie malnutrition (PCM) on the distribution of dexamethasone in maternal and foetal compartments as a function of time on day 20 of gestation in rats

\begin{tabular}{|c|c|c|c|c|c|c|c|}
\hline Group & $\begin{array}{c}\text { Time } \\
\text { (h) }\end{array}$ & $\begin{array}{r}\text { Serum (M) } \\
\text { (pm) }\end{array}$ & $\begin{array}{l}\operatorname{Serum}(F) \\
\left.\mathrm{ll}^{-1}\right)\end{array}$ & Liver (M) & $\begin{array}{l}\text { Liver (F) } \\
\left(\mathrm{pmol} \mathrm{g}^{-1} \mathrm{v}\right.\end{array}$ & $\begin{array}{l}\text { Lung (F) } \\
\text { t tissue) }\end{array}$ & Placenta \\
\hline $\mathrm{C}$ & 0.25 & $4840 \pm 321$ & $428 \pm 51$ & not done & not done & not done & not done \\
\hline PCM & 0.25 & $4070 \pm 119$ & $645 \pm 54^{*}$ & not done & not done & not done & not done \\
\hline $\mathrm{C}$ & 1 & $4460 \pm 270$ & $538 \pm 33$ & $15843 \pm 518$ & $2963 \pm 207$ & $1476 \pm 367$ & $3794 \pm 587$ \\
\hline PCM & 1 & $4042 \pm 571$ & $768 \pm 64^{*}$ & $16223 \pm 3226$ & $2853 \pm 495$ & $1349 \pm 38$ & $3677 \pm 729$ \\
\hline C & 3 & $2996 \pm 298$ & $466 \pm 71$ & $14991 \pm 849$ & $1606 \pm 140$ & $1109 \pm 101$ & $3649 \pm 497$ \\
\hline PCM & 3 & $2641 \pm 150$ & $758 \pm 90^{*}$ & $16366 \pm 2751$ & $2942 \pm 584^{*}$ & $1918 \pm 202^{*}$ & $4835 \pm 413$ \\
\hline C & 6 & $785 \pm 74$ & $229 \pm 10$ & $5252 \pm 540$ & $559 \pm 52$ & $266 \pm 77$ & $958 \pm 245$ \\
\hline PCM & 6 & $1015 \pm 139$ & $326 \pm 37^{*}$ & $6953 \pm 1569$ & $920 \pm 79^{*}$ & $557 \pm 81^{*}$ & $1471 \pm 301$ \\
\hline $\mathrm{C}$ & 9 & $438 \pm 31$ & $135 \pm 30$ & not done & not done & not done & not done \\
\hline PCM & 9 & $828 \pm 115$ & $263 \pm 31^{*}$ & not done & not done & not done & not done \\
\hline C & 12 & $326 \pm 41$ & $122 \pm 15$ & $1458 \pm 274$ & $207 \pm 22$ & $144 \pm 14$ & $450 \pm 87$ \\
\hline PCM & 12 & $244 \pm 62$ & $144 \pm 14$ & $1750 \pm 354$ & $340 \pm 26^{*}$ & $185 \pm 57$ & $310 \pm 60$ \\
\hline
\end{tabular}

Means \pm s.e.; $n=4-10$.

Dexamethasone levels in the maternal (M) and foetal (F) tissues of control (C) and PCM rats were determined at the time indicated following an i.v. injection of $4 \mu \mathrm{mol} \mathrm{kg}{ }^{-1}$ of the steroid.

* Different $(P<0.05)$ from the corresponding control value at equivalent time period. 
Table 3 Influence of protein-calorie malnutrition (PCM) on the distribution of dexamethasone in maternal (MS) and foetal (FS) serum $3 \mathrm{~h}$ following i.v. injections of the steroid at three different dose levels in rats on day 20 of gestation

\begin{tabular}{|c|c|c|c|c|}
\hline Animals & $\begin{array}{c}\text { Dose } \\
\left(\mu \mathrm{mol} \mathrm{kg}^{-1}\right)\end{array}$ & ${ }^{M S}$ (pmi & $-1)$ & $(F S / M S) \times 100$ \\
\hline Control & 0.8 & $505 \pm 53$ & $98 \pm 23$ & $19 \pm 3.5$ \\
\hline PCM & 0.8 & $558 \pm 48$ & $237 \pm 51^{*}$ & $41 \pm 5.4^{*}$ \\
\hline Control & 4.0 & $2996 \pm 298$ & $467 \pm 71$ & $27 \pm 2.0$ \\
\hline PCM & 4.0 & $2641 \pm 150$ & $758 \pm 90^{*}$ & $33 \pm 0.9^{*}$ \\
\hline Control & 20.0 & $22396 \pm 1772$ & $4623 \pm 393$ & $21 \pm 2.0$ \\
\hline PCM & 20.0 & $18929 \pm 1130$ & $6492 \pm 522^{*}$ & $35 \pm 3.2^{*}$ \\
\hline
\end{tabular}

rats. However, the $t_{1 / 2}$ of dexamethasone in pregnant rats with PCM was greater than that in nonpregnant controls and $V_{d}$ was greater than in all other groups of rats (control and PCM nonpregnant, control pregnant).

Maternal-foetal distribution of dexamethasone as a function of time (Table 2)

Significant amounts of dexamethasone reached the foetus within $15 \mathrm{~min}$ after its administration into the mother. In both groups of rats (control and PCM), dexamethasone concentration in tissues was greater than that in the serum. In general, dexamethasone levels in various foetal tissues (serum, livers and lungs) of PCM rats were higher than those in control foetal tissues.

Table 4 Influence of protein-calorie malnutrition (PCM) on the binding of $\left[{ }^{3} \mathrm{H}\right]$-dexamethasone to maternal and foetal serum proteins of rats on day 20 of gestation

$\begin{array}{lcc}\text { Serum source } & \begin{array}{c}\text { Serum proteins } \\ \left(\mathrm{g} \mathrm{dl}^{-1}\right)\end{array} & \begin{array}{c}\text { Dexamethasone bound } \\ (\%)\end{array} \\ & & \\ \text { Control mother } & 5.9 \pm 0.3 & 84 \pm 1.9 \\ \text { Control foetus } & 2.3 \pm 0.2^{*} & 83 \pm 1.0 \\ \text { PCM mother } & 3.8 \pm 0.2^{* *} & 82 \pm 1.7 \\ \text { PCM foetus } & 2.2 \pm 0.2^{*} & 76 \pm 2.1\end{array}$

Because the binding at all the 3 different concentrations of $\left[{ }^{3} \mathrm{H}\right]$-dexamethasone $(0.62,10.8$ and $102.5 \mathrm{nM}$ ) was identical, values for the same serum sample were averaged to yield one mean. Data are means \pm s.e. of 4 separate serum samples.

*Different $(P<0.05)$ from maternal values; ** different $(P<0.05)$ from the control maternal value.
Placental transfer of dexamethasone as a function of dose (Table 3)

There was a dose-dependent increase in maternal and foetal serum dexamethasone concentrations in both control and PCM rats. However, the ratios of foetal to maternal serum dexamethasone concentrations did not appreciably change as the dose of the steroid was increased. At all dose levels studied, foetal serum dexamethasone concentrations as well as the ratios of foetal to maternal serum concentrations of dexamethasone were higher in PCM than in control animals.

Placental transfer of dexamethasone as a function of gestational age (Figure 1)

Gestational age exerted no significant effect on maternal serum dexamethasone levels in both groups of rats. However, dexamethasone levels in the whole foetus and the amniotic fluid were lower on day 14 than on days 17-21 of gestation in control as well as PCM animals. In general, dexamethasone levels in foetuses of PCM rats were higher than those in control foetuses at various gestational ages.

\section{Placental metabolism of dexamethasone}

In vitro metabolism of dexamethasone by placental tissue from control rats at 2 and $4 \mu \mathrm{M}$ concentrations was $4.9 \pm 1.8 \%$ and $7.8 \pm 2 \%$, respectively. 11Dehydrodexamethasone was the only metabolite that could be detected by h.p.l.c. PCM exerted no significant effect on the placental metabolism of dexamethasone.

Serum protein-dexamethasone binding (Table 4)

There was no significant difference in the binding of 


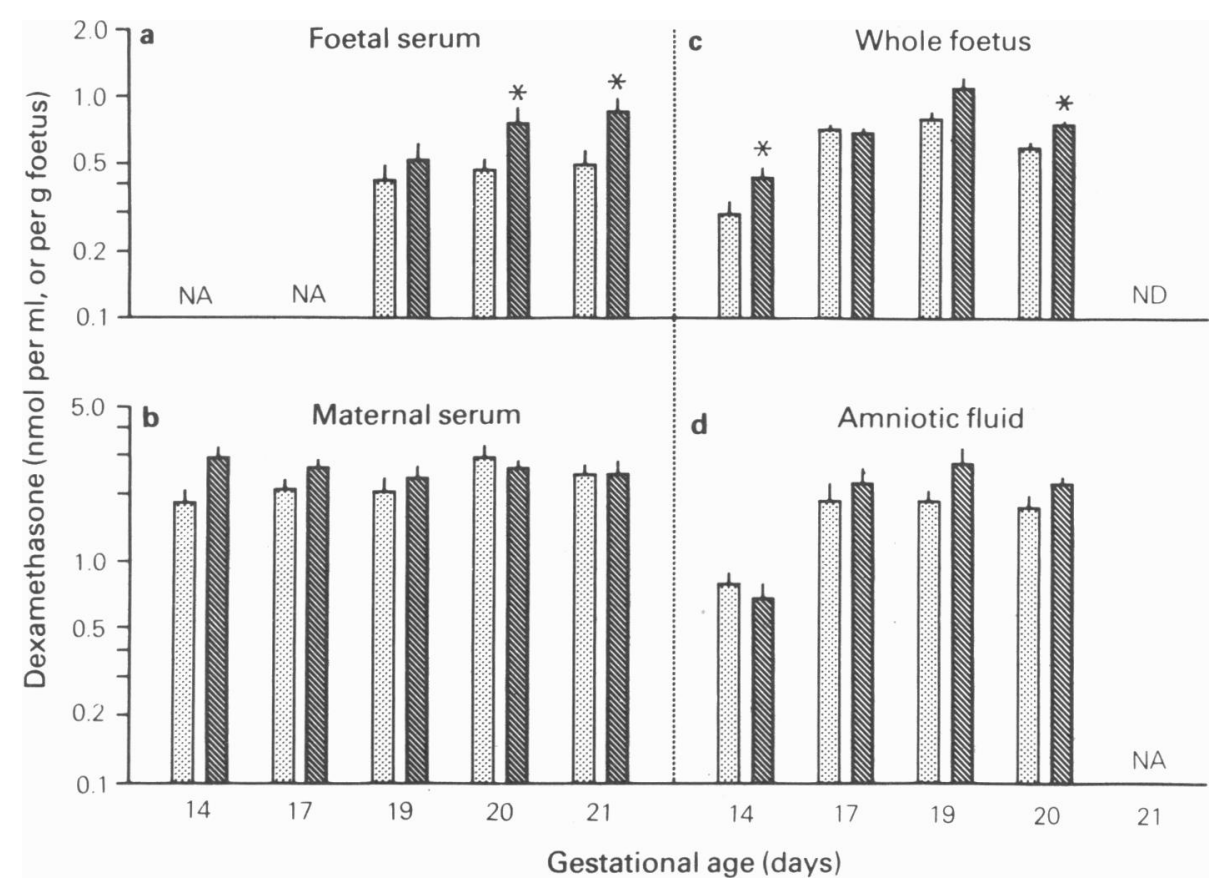

Figure 1 Influence of protein-calorie malnutrition (PCM) on the placental transfer of dexamethasone at different gestational ages in rats. Animals were fed ad libitum a $21 \%$ (control, stippled columns) or a 5\% (PCM, hatched columns) protein diet. Dexamethasone $\left(4 \mu \mathrm{mol} \mathrm{kg}^{-1}\right)$ was injected i.v. and animals killed $3 \mathrm{~h}$ later. Columns represent means and vertical lines s.e. of results from 4-10 animals. Asterisks denote difference $(P<0.05)$ from the control values at the same gestational age. NA, samples not available; ND, sample not done.

dexamethasone to maternal and foetal serum proteins from both groups of rats. PCM exerted no significant effect on serum protein-dexamethasone binding.

\section{Discussion}

The main objective of this study was to determine the influence of PCM on the maternal-foetal exchange of dexamethasone. The suitability of the protocol for inducing PCM (Mulay et al., 1982; Varma \& Yue, 1983) and of the techniques for the quantitation of dexamethasone by radioimmunoassay (Varma \& Mulay, 1980) and by h.p.l.c. (Kream et al., 1983) have been described previously. However, the transplacental passage of dexamethasone was not determined at steady-state conditions. Therefore, the present data are more suited for a comparison of dexamethasone levels in foetal compartments of control and PCM rats than for deriving transplacental kinetics.

PCM did not alter the pharmacokinetics of dexamethasone in nonpregnant rats (Table 1) as has been found in male rats (Varma \& Mulay, 1980) but increased the plasma $t_{1 / 2}$ and volume of distribution in pregnant animals. The mechanism of PCMinduced changes in the pharmacokinetics of dexamethasone in pregnant rats was not investigated; it would seem that the observed increase in $t_{1 / 2}$ is the result of an increase in the volume of distribution of dexamethasone, which in turn could be caused by an accentuation of any of the pregnancy-associated factors that can alter drug distribution (Krauer et al., 1980). However, a contributory role of PCMinduced decrease in dexamethasone metabolism in the prolongation of its plasma half-life cannot be excluded.

The finding that dexamethasone level in the foetal serum did not exceed $40 \%$ of that in the maternal serum for long periods is in conformity with data on the maternal-foetal exchange of this agent in rats (Funkhouser et al., 1978), sheep (Bayard et al., 1972; Anderson et al., 1979) and man (Kream et al., 1983) as well as with data on the transplacental passage of other synthetic glucocorticoids such as triamcinolone acetonide (Slikker et al., 1982), betamethasone (Ballard et al., 1975) and prednisolone (Beitins et al., 1972). Because the binding of dexamethasone to maternal and foetal serum proteins is not different as 
has also been reported by others (Funkhouser et al., 1978) and its metabolism by the placenta is insignificant, it seems improbable that significantly lower foetal than maternal serum dexamethasone concentrations are maintained by these factors. Theoretically, dexamethasone levels in the foetal serum should equal or exceed those in the maternal serum with time (Szeto, 1982). The fact that this is not so suggests that some uncharacterized efficient mechanism operates for the elimination of dexamethasone, and possibly other xenobiotics, by the foeto-placental unit.

As expected, the higher the dose of dexamethasone the higher was its concentration in both the maternal and foetal serum (Table 3). However, ratios of foetal to maternal serum dexamethasone levels remained relatively constant at all dose levels. It is tempting to suggest that if ratios of foetal to maternal serum levels of a drug remain constant over a wide dose range and time period in man, a knowledge of this ratio on the basis of a selected number of studies could serve to approximate foetal serum levels of the drug on the basis of easily measurable maternal levels.

We previously showed that PCM increased the placental transfer of salicylate (Varma \& Yue, 1983). The present data show that this is also true for dexamethasone. The underlying mechanism for this effect of PCM is not clear from these studies. It does not appear to have been caused by any changes in the binding of dexamethasone to serum proteins, its metabolism by the placenta or transfer into the amniotic fluid. Because dexamethasone is a highly lipid soluble agent, it is unlikely that the rate or the magnitude of placental transfer from the mother to the foetus could be increased by PCM. It is possible that PCM-induced increase in the foetal levels of dexamethasone is caused by an impairment of the mechanism responsible for its elimination by the foeto-placental unit.

Whatever the mechanism is for a relatively higher level of dexamethasone in foetuses of PCM than of control rats, the present data indicate that in so far as the rat model reflects the human situation, a given dose of dexamethasone might exert a greater effect on the foetus in the presence than in the absence of maternal protein-calorie malnutrition. The fact that PCM is also associated with increases in maternal and foetal liver glucocorticoid receptor levels (Mulay et al., 1982; Varma et al., 1982) could imply an even greater effect of glucocorticoids than is likely to occur merely because of the increased foetal localization of these agents.

We wish to thank Ms Christine Schwenter for her skilled technical assistance. This work was partly supported by a grant from the Medical Research Council of Canada (MA6981).

\section{References}

ANDERSON, D.F., STOCK, M.K. \& RANKIN, J.H.G. (1979). Placental transfer of dexamethasone in near-term sheep. J. Develop. Physiol., 1, 431-436.

AVERY, M.E. (1975). Pharmacological approaches to the acceleration of fetal lung maturation. Br. med. Bull., 31, 13-17.

BALLARD, P.L., GRANBERG, P. \& BALLARD, R.A. (1975). Glucocorticoid levels in maternal and cord serum after prenatal betamethasone therapy to prevent respiratory distress syndrome. J. clin. Invest., 56, 1548-1554.

BAYARD, F., LOUVET, J.P., RUCKEBUSCH, Y. \& BOULARD, CL. (1972). Transplacental passage of dexamethasone in sheep. $J$. Endocr., 54, 349-350.

BEITINS, I.Z., BAYARD, F., ANCES, I.G., KOWARSKI, A. \& MIGEON, C.J. (1972). The transplacental passage of prednisone and prednisolone in pregnancy near term. $J$. Pediatr., 81, 936-945.

BLANFORD, A.T. \& MURPHY, B.E.P. (1977). In vitro metabolism of prednisolone, dexamethasone and cortisol by the human placenta. Am. J. Obstet. Gynec., 127, 264-267.

FRASER, F.C., KALTER, H., WALDER, B.E. \& FAINSTAT, T.D. (1954). The experimental production of cleft palate with cortisne and other hormones. J. Cell comp. Physiol., 43 (Suppl. 1), 237-259.

FUNKHOUSER, J.D., PEEVY, K.J., MOCKRIDGE, P.B. \&

HUGHES, E.R. (1978). Distribution of dexamethasone between mother and fetus after maternal administration. Pediatr. Res., 12, 1053-1056.

KRAUER, B., KRAUER, F. \& HYTTEN, F.E. (1980). Drug disposition and pharmacokinetics in the maternalplacental-fetal unit. Pharmac. Ther., 10, 301-328.

KREAM, J., MULAY, S., FUKUSHIMA, D.K. \& SOLOMON, S. (1983). Determination of plasma dexamethasone in the mother and the newborn after administration of the hormone in a clinical trial. J. clin. Endocr. Metab., 56, 127-133.

LOWRY, O.H., ROSEBROUGH, N.J., FARR, A.L. \& RANDALL, R.J. (1951). Protein measurement with Folin phenol reagent. J. biol. Chem., 193, 265-275.

MULAY, ., VARMA, D.R. \& SOLOMON, S. (1982). Influence of protein deficiency in rats on hormonal status and cytoplasmic glucocorticoid receptors in maternal and fetal tissues. J. Endocr., 95, 49-58.

SLIKKER, W., ALTHAUS, Z.R., ROWLAND, J.M., HILL, D.E. \& HENDRICKX, A.G. (1982). Comparison of the transplacental pharmacokinetics of cortisol and triamcinolone acetonide in the rhesus monkey. J. Pharmac. exp. Ther., 223, 368-374.

SZETO, H.H. (1982). Pharmacokinetics in the ovine maternal-fetal unit. A. Rev. Pharmac., 22, 221-243.

VARMA, D.R., KILBERTUS, F.T. \& MULAY, S. (1982). Phar- 
macological significance of changes in glucocorticoid receptors in protein-deficient young and adult rats of bothsexes and pregnant rats. J. Pharmac. exp. Ther., 223, 816-823.

VARMA, D.R. \& MULAY, S. (1980). Anti-inflammatory and ulcerogenic effects and pharmacokinetics of dexamethasone in protein-deficient rats. . Pharmac. exp. Ther., 214, 197-202.
VARMA, D.R. \& YUE, T.L. (1983). The influence of maternal protein deficiency on the placental transfer of salicylate in rats. Br. J. Pharmac., 78, 233-238.

WESTPHAL, U. (1969). Assay and properties of corticosteroid-binding globulin and other steroidbinding proteins. Methods Enzymol., 15, 761-796.

(Received December 30, 1983. Revised April 24, 1984.) 